\title{
OPEN Author Correction: Deposits from evaporating emulsion drops
}

\section{R. Bittermann, A. Deblais, S. Lépinay, D. Bonn \& N. Shahidzadeh}

Correction to: Scientific Reports https://doi.org/10.1038/s41598-020-71964-1, published online 10 September 2020

Published online: 08 October 2020

In this Article, the legend of Figure 2 is incorrect:

"Scale bar is $160 \mu \mathrm{m}$ ".

should read:

"Scale bars are $1 \mathrm{~mm}$ ".

Additionally, in the Results section under the subheading, 'Confinement and coalescence of oil droplets',

"At the complete formation of the depletion zones on the two more hydrophilic substrates, and around the onset of CCA evaporation on the hydrophobic substrate, we observe emulsion destabilization initiating at the contact line".

should read:

"At the complete formation of the depletion zones on the two more hydrophilic substrates, and around the onset of mixed mode evaporation on the hydrophobic substrate, we observe emulsion destabilization initiating at the contact line".

\begin{abstract}
(c) Open Access This article is licensed under a Creative Commons Attribution 4.0 International (c) License, which permits use, sharing, adaptation, distribution and reproduction in any medium or format, as long as you give appropriate credit to the original author(s) and the source, provide a link to the Creative Commons licence, and indicate if changes were made. The images or other third party material in this article are included in the article's Creative Commons licence, unless indicated otherwise in a credit line to the material. If material is not included in the article's Creative Commons licence and your intended use is not permitted by statutory regulation or exceeds the permitted use, you will need to obtain permission directly from the copyright holder. To view a copy of this licence, visit http://creativecommons.org/licenses/by/4.0/.
\end{abstract}

(c) The Author(s) 2020 